\title{
Effects of Brand Loyalty, Image and Quality on Brand Equity: A Study among Bank Islam Consumers in Kelantan, Malaysia
}

\author{
Archana Subramaniam ${ }^{1}$, Abdullah Al Mamun ${ }^{1}$, P. Yukthamarani Permarupan ${ }^{1} \&$ Noor Raihani Binti Zainol $^{1}$ \\ ${ }^{1}$ Faculty of Entrepreneurship and Business, Universiti Malaysia Kelantan, Malaysia \\ Correspondence: Abdullah Al Mamun, Faculty of Entrepreneurship and Business, Universiti Malaysia Kelantan, \\ Malaysia. Tel: 60-13-300-3630. E-mail: mamun7793@gmail.com; abdullah.a@umk.edu.my
}

Received: January 30, 2014

doi:10.5539/ass.v10n14p67
Accepted: May 19, 2014 Online Published: June 24, 2014

URL: http://dx.doi.org/10.5539/ass.v10n14p67

\begin{abstract}
The objective of this study is to investigate how brand loyalty, brand image, and perceived quality affect the brand equity of Bank Islam, based on the evaluation and prioritization of brand equity dimensions from the customers' viewpoint. This study employed a cross-sectional design and used a self-administered questionnaire and collected data from 200 clients of Bank Islam from Kelantan, Malaysia. Findings of this study noted that brand loyalty and brand image has a significant positive contribution to brand equity. Bank Islam should, therefore, focus on designing products and services that benefit clients more than or equal to the conventional banks, within the borderline of Islamic Banking practices.
\end{abstract}

Keywords: brand loyalty, image and quality on brand equity, Bank Islam, Malaysia

\section{Introduction}

In order to survive in today's competitive business environment, organizations have to be able to obtain a competitive advantage over the competitors and increase their market share. To obtain competitive advantages over competitors and to increase market share, organizations commonly focus on designing new products, improving the existing products, and building a brand image. A positive brand image is vital for product management and marketing communication (Erenkol \& Duygun, 2010). A well-established and renounced brand image can be considered as one of the most valuable assets for any organization as it facilitates in obtaining greater customer loyalty, higher profit margin, improved cooperation and support, and increased marketing communication effectiveness (Olson, 2009). This is why organizations emphasize on building a strong brand image by establishing the brand meaning in the minds of consumers by linking brand associations, which ultimately lead to higher loyalty relationship between customers and the organization.

Brand equity, as defined by Pride and Ferrell (2003), is the marketing and financial value associated with a brand's strength in the market, including actual proprietary brand assets, brand name awareness, brand loyalty, perceived brand quality, and brand associations. When a trading organization possesses high brand equity, it allows the organization to reduce marketing expenses, as consumers are already aware and loyal. Moreover, since the loyal consumers tend to go where they can find the product they are looking for; these allow the organization to possess more power over distributors and retailers (Pouromid \& Iranzadeh, 2012). The loyal consumers also attract new undetermined consumers. Brand equity is an incremental utility and considered as one of the sources of competitive advantage by many firms (Hao et al., 2007). Therefore, brand equity is appreciated as the most esteemed intangible assets for any company deals with large number of consumers.

Brand equity has become immensely important for service-based organizations in recent years, for services that are identical and difficult to differentiate. Many service organizations such as banking, telecommunication, airlines, and hotels are facing competition and it is important for the service providers to establish a strong brand (H. Kim \& W. Kim, 2005). As such, a strong brand image is important for managers of service organizations (Kimpakorn \& Tocquer, 2010). Understanding brand equity from a customer's perspective help marketers to explore the purchase behavior and to design effective marketing programs (Kimpokorn \& Tocquer, 2010). As service organizations offer almost identical products and services, building a strong brand image is expected to be a very complicated task. However, due to its importance and positive role in business survival, service organizations with identical products are focused on strengthening their brand image. 
Bank Islam Malaysia Berhad (BIMB) was established in July 1983. It was Malaysia's first licensed 'Bank Islam', which was established under the Islamic Banking Act (IBA). Bank Islam offered products and services based on Islamic principles in Malaysia. Consequently, the competition from other banks began to increase, offering products and services in the same market segmentation. Thus, brand equity has become more important in determining customer satisfaction, which is potentially an effective tool that 'Bank Islam' can use to enrich the strategic competitive advantage in the banking market.

The banking sector in almost every economy is one of the most competitive service industries. Moreover, most of the products and services offered are almost identical. It is therefore, crucial for the banking industry to build brand equity in order to sustain in the competitive business environment. Understanding the different aspects of the brand and its relations with customers might therefore provide invaluable insight in designing effective marketing tools and proper resource allocation. This study therefore, is focused on determining the brand equity level of 'Bank Islam' through the dimensions of brand loyalty, brand image, and perceived quality, as the evaluation and prioritization of brand equity dimensions from a customer's viewpoint are very important.

\section{Literature Review}

Brand equity refers to a brand's power derived from the goodwill and name recognition that it has earned over time, which translates into higher sales volume and higher profit margins against competing brands. Customer Based Brand Equity (CBBE) represents the consumer's perspective of brand equity and as defined by King and Grace (2010), is 'the differential effect that brand knowledge has on consumer response to the marketing of that brand'. Keller (2001) stated that CBBE model provides assistance in building a brand as it can be used to interpret why some brands fail to become strong brands, how strong brands are in trouble, and what makes an online brand impressive. Ukpebor and Ipogah (2008) indicate that brand equity consists of three dimensions: perceived quality, brand loyalty and brand image.

Brand equity requires an extension in the context of marketing because of the differences between goods and services. Krishnan and Hartline (2001) noted that brand equity is more important for products than for services. According to Yoo and Donthu (2001), consumer-based brand equity scale is functional for processing information and building confidence in the purchase decision and for enhancing efficiency and effectiveness of marketing programs, price, profits and brand extensions, and trade leverage. In their study, they stated that the new brand equity scale is applicable, reliable, and relevant in different product categories in different cultures. They pointed out that three and four dimension models that comprise of brand loyalty, perceived quality, brand awareness, and brand association are valid to identify brand equity.

Aziz and Yasin (2010) described the brand resonance model, which considers six issues namely brand performance, brand judgment, brand feelings, brand resonance, and brand salience, to identify brand equity of services. This study only considered the determinants of brand equity of services. In order to achieve high brand equity, the organization requires customers' recall and brand recognition, followed by rendering customer's cognition to have a positive brand image of a particular brand to a feasible extent and finally, to induce their repurchase intention of the product or service. Based on the studies noted above, this study selected three key dimensions to determine the brand equity level of Bank Islam.

\subsection{Brand Loyalty}

Loyalty can be defined as the commitment to repurchase superior goods or services in the future, despite competitors' efforts. Customer commitment is one of the outcomes of an organization, which generates advantages for customers so that they keep on increasing their purchase from the same organization. From a sales promotion point of view, customer loyalty is established when they are motivated to purchase without any encouragement. From a consumer behavior point of view, brand loyalty defined as the degree to which a consumer consistently purchased the same brand within a product class (Sriram et al., 2007). Loyal customers do not only focus on price but also act as a fan of the organization and as a result, help to attract new customers. The physical aspect of a brand is found in the physical service offering or the product itself, whereas the perceptual aspect is found in the physiological space and therefore the consumers mind. This implies that consumers experience brand loyalty differently. This places an enormous task on brand managers in assisting the company to realize the benefits of brand loyalty such as company sustainability and profitability, and ensuring that new customer acquisition costs are limited to a minimum.

\subsection{Brand Image}

Brand is described as the name of a design, symbol or other features that identifies the products/services and how it relates. Branding image is adapted to differentiate one product/service with another product/service. Brand also 
plays an important role in an advertising theme, as it describes the brand offered in the market place. Brand image is also the totality of consumer perception of a brand, which does not coincide with the brand identity. It consists of functional and symbolic brand beliefs. Brand image associations are largely product category specific and measures should be customized for the unique characteristics of specific brand categories. The factors, which may prevent consumers from converting their attitudes into intentions and buying behavior are numerous and frequent.

Keller (1993) described that the benefits from brand image can be classified into functional, experiential and symbolic benefits. Hsieh, Pan, \& Setiono (2004) noted that brand image helps consumers in recognizing their needs and satisfaction regarding a brand, and to buy the brand. Thaker (2006) explains that brand image can be a thought of natural traits and it has a special relation to the brand identity concept. The brand identity is a set of human traits weaned into a brand. As noted by Brodie et al. (2009), personality stimulation assessments explain why a consumer may have emotional dependency to one brand and not the other.

\subsection{Perceived Quality}

Perceived quality is one of the crucial factors contributing brand equity. It is the core construct to measure brand equity. Perceived quality has been the subject of considerable interest by both practitioners and researchers, mainly in service marketing. The role of perceived quality is integrated within the context of other marketing variables like product involvement, consumer satisfaction, and purchase intention.

Perceived quality is defined as the consumer's judgment about a product's overall excellence or superiority. Perceived quality explains a considerable position of the variance in the premium prices that consumers are willing to pay for actual brands (Sethuraman \& Cole, 1997). The perceived quality of products and services of strong brands add value to consumers purchase evaluations. Lee et al. (2010) noted that when consumers perceive a brand to be of high quality, they are more likely to purchase the brand over competing brands, pay a premium price and choose the brand. Perceived quality and perceived value play important roles in industries with high customer involvement, such as the banking industry. Therefore, it is important to identify dimensions of these constructs correctly and to find out how the constructs are perceived by customers. Perceived quality is also a component of brand value, which leads consumers to select a particular brand rather than another competing brand (Yoo et al., 2000).

\section{Methodology}

The primary objective of this study is to examine the brand equity dimensions from a customer's viewpoint. This study employed a cross sectional design and the convenient sampling method was used to collect data from a total of 200 Bank Islam clients. A self-administered questionnaire was prepared to collect quantitative data from the clients of Bank Islam's branches in Kelantan, Malaysia. The type of instruments that was used in this research was the five-point Likert scale questionnaires. Likert scale is the easiest way to build based upon the supposition that each statement on the scale has an attitude value, importance or weight in reflecting the attitude towards the issue in question. There are also multiple-choice questions in this questionnaire. The survey questionnaire was divided into two sections. Section A includes demographic factors such as age, gender, ethnicity, education and employment while the dependent variable is tested in Section B, which is brand equity. Sections $\mathrm{C}, \mathrm{D}$, and $\mathrm{E}$ test the independent variables such as brand loyalty, brand image, and perceived quality. Five assigned points, 1, 2, 3, 4, and 5, are used to represent the term of strongly disagree, disagree, neutral, agree, and strongly agree as in the order of the numbers.

The questionnaire in Section B contains the questions pertaining to brand equity. Using a 5-point Likert scale, respondents are asked to answer the questions. Five assigned points, 1, 2, 3, 4, and 5, are used to represent the terms of strongly disagree, disagree, neutral, agree, and strongly agree. Brand loyalty is assessed using items from 12 dimensions: brand performance, brand trust, commitment, switching costs, customer satisfaction, culture, involvement, repeat purchase, brand relevance, relationship proneness, and perceived value. The respondents can indicate their answers by using a 5-point scale ranging from 1-5, strongly disagree to strongly agree.

\section{Summary of Findings}

\subsection{Demographic Characteristics}

To examine the brand equity dimensions from the customers' viewpoint, a complete data was collected from 200 clients of Bank Islam. Out of the 200 respondents, 79 (39\%) are male and the remaining $121(61 \%)$ are female. A majority of the respondents are from the 20-29 age group, which is about $57 \%$, followed by 20 or less age group with 20\%, and 30-39 age group with 14\%. The respondents of the 40-59 age group accounted for the remaining $9 \%$. As for the race of the respondents, out of the total 200 respondents, 101 are Malays, 58 are Chinese, and 33 
are Indians. 95 out of the total 200 respondents had completed their bachelor degree, whereas 53 respondents completed Diploma, 39 respondents completed SPM and the remaining 13 completed masters and above.

\subsection{Reliability Analysis}

The interim consistency of the data collected was measured. The result indicates that the Cronbach's alpha of the brand loyalty measure is 0.887 , brand image measure is 0.886 , perceived quality measure is 0.956 , and brand equity measure is 0.829 . Thus, the internal consistency reliability of the measures used in this study can be considered as being in the range of very good.

Table 1. Reliability analysis

\begin{tabular}{lll}
\hline Variable & N of Items & Cronbach's Alpha Based on Standardized Items \\
\hline Brand Loyalty & 12 & 0.887 \\
Brand Image & 6 & 0.886 \\
Perceived Quality & 17 & 0.956 \\
Brand Equity & 5 & 0.829 \\
\hline
\end{tabular}

\subsection{Exploratory Analysis}

As presented in Table 2 below, findings indicate that the skewness of the distribution for all variables is normal as skewness values ranged within -1.0 to +1.0 . The mean and standard deviation are also presented in Table 2 .

Table 2. Descriptive statistics of variables

\begin{tabular}{lllll}
\hline & Brand Loyalty & Brand Image & Perceived Quality & Brand Equity \\
\hline $\mathrm{N}$ & 200 & 200 & 200 & 200 \\
Mean & 3.42 & 3.69 & 3.65 & 3.64 \\
Std. Deviation & 0.704 & 0.721 & 0.672 & 0.754 \\
Variance & 0.496 & 0.520 & 0.452 & 0.569 \\
Skewness & -0.121 & -0.459 & -0.197 & -0.524 \\
Kurtosis & -0.148 & 0.519 & -0.138 & 0.028 \\
\hline
\end{tabular}

\subsection{Correlation Analysis}

The Pearson Correlation test was employed to examine the association between variables. As noted in Table 3, it shows that all the variables have moderate significant positive correlation with brand equity, which is Brand Loyalty $(r=0.759)$, Brand Image $(r=0.683)$, and Perceived Quality $(r=0.646)$. The correlation coefficients among independent variables are also not more than 0.9 , which eliminates the multicollinearity issue. Multicollinearity issue was also verified with variance inflation factor (VIF) values noted in Table 9.

Table 3. Correlation analysis

\begin{tabular}{llllll}
\hline & & Brand Equity & Brand Loyalty & Brand Image & Perceived Quality \\
\hline \multirow{4}{*}{ Pearson Correlation } & Brand Equity & 1.000 & & & \\
& Brand Loyalty & .759 & 1.000 & & \\
& Brand Image & .683 & .731 & 1.000 & \\
& Perceived Quality & .646 & .693 & .838 & 1.000 \\
& Brand Equity & & & & \\
Sig. (1-tailed) & Brand Loyalty & .000 & & & \\
& Brand Image & .000 & .000 & & \\
& Perceived Quality & .000 & .000 & .000 & 200 \\
$\mathrm{~N}$ & & 200 & 200 & 200 & \\
\hline
\end{tabular}




\subsection{Assumptions for Regression Analysis}

In the lack of fit test, the probability of the $\mathrm{F}$ test statistic $(\mathrm{F}=0.800)$ was $p=0.748$, which is higher than the chosen $5 \%$ level of significance, indicates that a linear regression model is appropriate as it satisfies the linearity assumption.

Table 4. Lack of fit tests

\begin{tabular}{llllll}
\hline Source & Sum of Squares & df & Mean Square & F & Sig. \\
\hline Lack of Fit & 40.334 & 184 & .219 & .800 & .748 \\
Pure Error & 3.290 & 12 & .274 & & \\
\hline
\end{tabular}

The $p$ value for the Levene's test for equality of variance for brand equity, brand loyalty, brand image, and perceived quality are noted in Table 5 below. As the $p$ values for all variables are more than the chosen $5 \%$ level of significance, equality of variances can be assumed. This finding satisfies the assumption of homoscedasticity.

Table 5. Levene's test for homogeneity of variance

\begin{tabular}{lllll}
\hline & Brand Equity & Brand Loyalty & Brand Image & Perceived Quality \\
\hline F & 2.619 & 1.059 & 0.008 & 0.092 \\
Sig & 0.112 & 0.309 & 0.927 & 0.763 \\
\hline
\end{tabular}

The value of the Durbin-Watson statistic ranges from 0 to 4 . As a general rule of thumb, the residuals are not correlated if the Durbin-Watson statistic is approximately 2, and an acceptable range is 1.50 to 2.50 . The Durbin-Watson statistic for this problem is 1.864 (Table 7), which falls within the acceptable range of 1.50 to 2.50. The analysis satisfies the assumption of independence of errors. The variance inflation factor (VIF) values for brand loyalty, brand image and perceived quality, as noted in Table 9, are 2.254, 3.936, and 3.524 respectively, which is less than 10 , therefore satisfying the assumption of the absence of multicollinearity.

Table 6. Tests of normality

\begin{tabular}{lllllll}
\hline & \multicolumn{2}{l}{ Kolmogorov-Smirnov $^{\mathrm{a}}$} & \multicolumn{3}{l}{ Shapiro-Wilk } \\
& Statistic & df & Sig. & Statistic & df & Sig. \\
\hline Standardized Residual & .071 & 200 & .017 & .991 & 200 & .232 \\
\hline
\end{tabular}

The Shapiro-Wilk test of standardized residuals yielded a statistical value of 0.991 , which had a probability of $p$ $=0.232$, that is within the chosen $5 \%$ level of significance, therefore satisfying the assumption of normality.

\subsection{Multiple Regression Analysis}

The $r^{2}$ value, as presented in Table 7, determines the amount of the explained variation (variance) in brand equity (dependent variable) from the three variables on a range of 0-100 percent. Thus, the study is able to state that $61.4 \%$ of the variation in brand equity is accounted for through the combined linear effect of the predictor variables, i.e. brand loyalty, brand image, and perceived quality.

Table 7. Model summary

\begin{tabular}{lllll}
\hline $\mathrm{R}$ & R Square & Adjusted R Square & Std. Error of the Estimate & Durbin-Watson \\
\hline .784 & .614 & .609 & .472 & 1.864 \\
\hline
\end{tabular}

The total variance is partitioned into the variance that can be explained by the independent variables (Regression) and the variance, which cannot be explained by the independent variables (Residual). As noted in the ANOVA in Table 8, the sum of squares is the total variance (113.133), which includes Regression (69.509) and Residual (43.624). The $p$ value for $\mathrm{F}$ test is 0.00 , which is less than the chosen $5 \%$ level of significance, indicating a good model fit. These indicates that the three selected independent variables, which are brand loyalty, brand image, and 
perceived quality, can be used to predict brand equity.

Table 8. Analysis of variance

\begin{tabular}{llllll}
\hline Model & Sum of Squares & df & Mean Square & F & Sig. \\
\hline Regression & 69.509 & 3 & 23.170 & & \\
Residual & 43.624 & 196 & 0.223 & & 0.000 \\
Total & 113.133 & 199 & & & \\
\hline
\end{tabular}

Findings in Table 9 indicate that brand loyalty and brand image are significant factors contributing to brand equity, as the $p$-value is less than the chosen $5 \%$ level of significance. The perceived quality coefficient is positive, indicating a positive effect of perceived quality on brand equity. However, the $p$ value for perceived quality is more than the chosen $5 \%$ level of significance, which means the data do not provide enough evidence to conclude that the positive effect of perceived quality on brand equity exists in the population. As for the brand image, the regression coefficient is positive $(\beta=0.210)$ and statistically significant (sig. $=0.024)$. In regards to brand loyalty, it has a positive $(\beta=0.579)$ and significant $(p=0.000$, which is less than the chosen $5 \%$ level of significance) effect on brand equity. The result explains that banks with a high level of brand loyalty generate higher brand equity.

Table 9. Regression coefficients

\begin{tabular}{|c|c|c|c|c|c|c|c|}
\hline & \multicolumn{2}{|c|}{ Unstandardized Coefficients } & \multirow{2}{*}{$\begin{array}{l}\text { Standardized Coefficients } \\
\text { Beta }\end{array}$} & \multirow{2}{*}{$\mathrm{t}$} & \multirow{2}{*}{ Sig. } & \multicolumn{2}{|c|}{ Collinearity Statistics } \\
\hline & $\beta$ & Std. Error & & & & Tolerance & VIF \\
\hline (Constant) & .463 & .192 & & 2.409 & .017 & & \\
\hline Brand of Loyalty & .579 & .071 & .541 & 8.119 & .000 & .444 & 2.254 \\
\hline Brand Image & .210 & .092 & .201 & 2.279 & .024 & .254 & 3.936 \\
\hline Perceived Quality & .116 & .093 & .104 & 1.246 & .214 & .284 & 3.524 \\
\hline
\end{tabular}

\section{Conclusion}

The findings of this study indicate a positive significant effect of brand loyalty and brand image on the brand equity of Bank Islam. Among the three factors noted in the regression model, brand loyalty has a much higher effect on brand equity than brand image and perceived quality. Consumer's loyalty plays a crucial role in the long-term survival of any industry. In the banking sector, where the services are almost identical, it is very difficult to get loyal customers. However, in this case, the product and services offered by Bank Islam is not that identical. Bank Islam has adopted the Islamic Banking system and provides consumers and businesses with Islamic banking services, as they are operating in a Muslim neighborhood, where consumers are commonly highly aware of what is halal (legal according to Islam). Over recent years, other Malaysian banks have also started Islamic banking; however, they commonly do it as a part of conventional banking. Consumers are already loyal even before they join Bank Islam because of its Islamic Banking policies and this has enabled Bank Islam to accumulate a strong brand image. However, this can be one of the crucial success factors only if the product and services offered by Bank Islam is equal to or better than other conventional banks in Malaysia. This is the key challenge for Bank Islam; designing products and services that benefit clients more than or equal to, what they can get from conventional banks, within the boundary of Islamic Banking Practices.

\section{References}

Aziz, N. A., \& Yasin, N. M. (2010). Analyzing the brand equity and resonance of banking services: Malaysian consumer perspective. International Journal of Marketing Studies, 2(2), 180-189. http://dx.doi.org/10.5539/ ijms.v2n2p180

Brodie, R., Whittome, J., \& Brush, G. (2009). Investigating the service brand: A customer value perspective. Journal of Business Research, 62, 345-355. http://dx.doi.org/10.1016/j.jbusres.2008.06.008

Erenkol, A. D., \& Duygun, A. (2010). Customers perceived brand equity and a research on the customers of Bellona which is a Turkish furniture brand. The Journal of American Academy of Business, 16(1), 93-109. 
Hao, L., Gao, C., \& Liu, Z. (2007). Customer-based brand equity and improvement strategy for mobile phone brands: Foreign versus local in the Chinese market. International Management Review, 3(3), 76-83.

Hsieh, M. H., Pan, S. L., \& Setiono, R. (2004). Product-, corporate-, and country-image dimensions and purchase behavior: A Multicounty Analysis. Journal of the Academy of Marketing Science, 32(3), 251-270. http://dx.doi.org/10.1177/0092070304264262

Keller, K. L. (1993). Conceptualizing, measuring and managing customer-based brand equity. Journal of Marketing, 57(1), 1-22. http://dx.doi.org/10.2307/1252054

Keller, K. L. (2001). Building Customer-Based Brand Equity: A Blueprint for creating Strong Brands. Marketing Science Institute Working Paper Series, 1-107. http://dx.doi.org/10.5089/9781451845358.001

Kim, H., \& Kim, W. (2005). The relationship between brand equity and firms performances in luxury hotels and chain restaurants. Tourism Management, 26, 549-560. http://dx.doi.org/10.1016/j.tourman.2004.03.010

Kimpakorn, N., \& Tocquer, G. (2010). Service brand equity and employee brand commitment. Journal of Services Marketing, 24(5), 378-388. http://dx.doi.org/10.1108/08876041011060486

King, C., \& Grace, D. (2010). Building and measuring employee-based brand equity. European Journal of Marketing, 44(7/8), 938-971. http://dx.doi.org/10.1108/03090561011047472

Krishnan, B. C., \& Hartline, M. O. (2001). Brand equity: Is it more important in services? Journal of Services of Marketing, 15(5), 328-342. http://dx.doi.org/10.1108/EUM0000000005654

Lee, H. J., Kumar, A., \& Ki, Y. K. (2010). Indian consumer's brand equity toward a US and local apparel brand. Journal of Fashion Marketing and Management, 14(3), 469-485. http://dx.doi.org/10.1108/1361202101 1061898

Olson, T. (2009). Build Business Using Social Networks. PC World. Retrieved from http://www.pcworld.com/businesscenter/article/159309/build_business_using_social_networks.html

Pouromid, B., \& Iranzadeh, S. (2012). The Evaluation of the Factors Effects on the Brand Equity of Pars Khazar Household Appliances Based on the Vision of Female Consumers. Middle-East Journal of Scientific Research, 12(8), 1050-1055.

Pride, W. M., \& Ferrell, O. C. (2003). Marketing: Concepts and Strategies. Boston, MA: Houghton Mifflin Company.

Sethuraman, R., \& Cole, C. (1997). Why do Consumers Pay More for National Brands than for Store Brands? Cambridge, MA: Marketing Science Institute, Report No. 97-126.

Sriram, S., Balachander, S., \& Kalwani, M. U. (2007). Monitoring the Dynamics of Brand Equity using Store-Level Data. Journal of Marketing, 71, 61-78. http://dx.doi.org/10.1509/jmkg.71.2.61

Thakor, M. (2006). Brand Origin: Conceptualization and Review. Journal of Consumer Marketing, 13(3), 27-42. http://dx.doi.org/10.1108/07363769610147929

Yoo, B., Donthu, N., \& Lee, S. (2000). An examination of Selected Marketing Mix Elements and Brand Equity. Journal of the Academy of Marketing Science, 28(2), 195-211. http://dx.doi.org/10.1177/00920703002820 02

\section{Copyrights}

Copyright for this article is retained by the author(s), with first publication rights granted to the journal.

This is an open-access article distributed under the terms and conditions of the Creative Commons Attribution license (http://creativecommons.org/licenses/by/3.0/). 